\title{
Encouragement and Contracting Factors for Implementation of Dynamic Village Institutional Program and Adaptive Culture in Minahasa Tenggara District
}

\author{
Deysi L. N. Tampongangoy ${ }^{1} \square$ Lusy K. R. R. Gerungan ${ }^{2}$ and Grace H. Tampongangoy ${ }^{3}$ \\ ${ }^{123}$ Sam Ratulangi University, Indonesia \\ $\square$ Corresponding Author: Deysi L. N. Tampongangoy, E-mail: deyslivitampongangoy@gmail.com
}

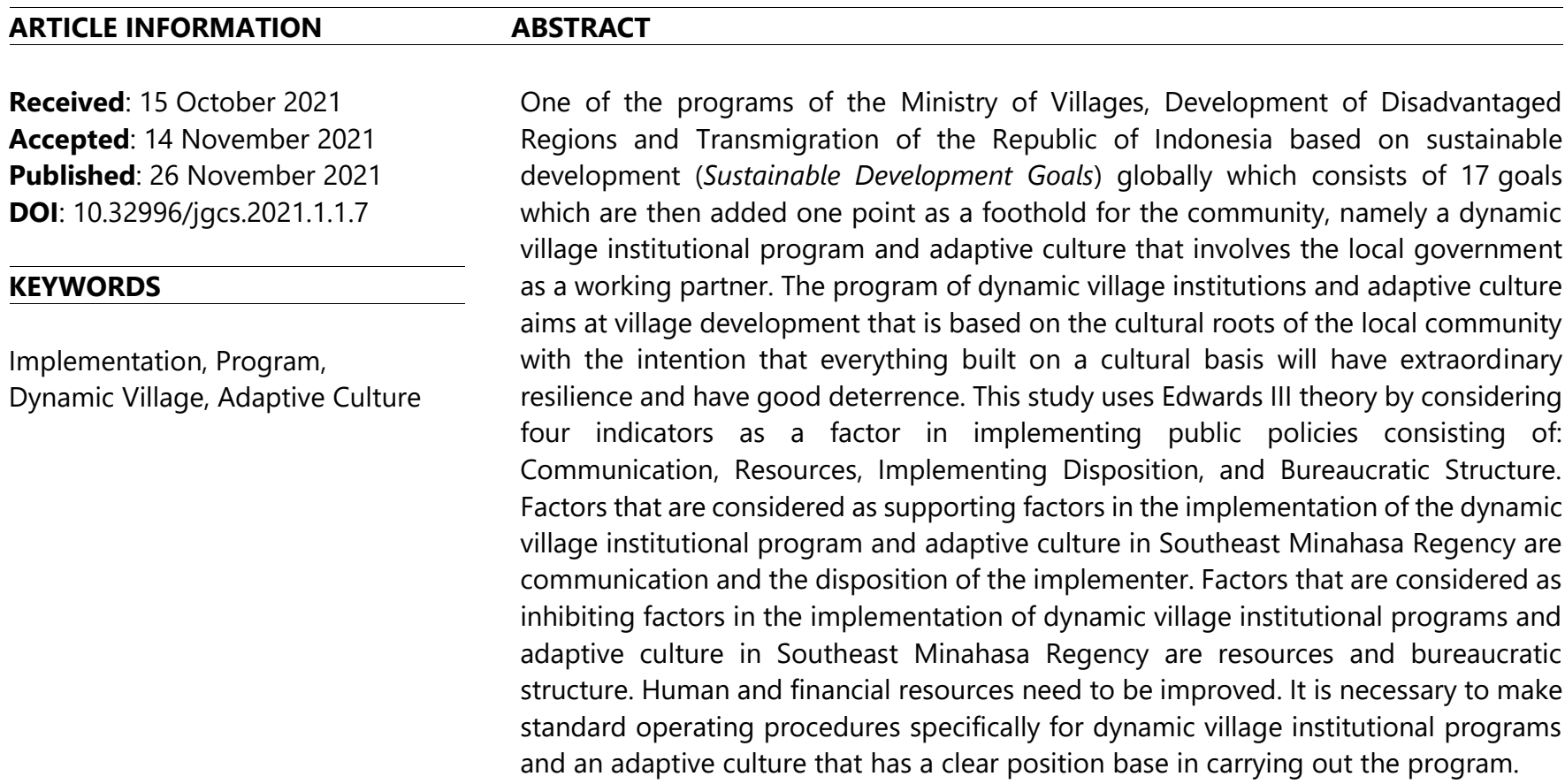

\section{Introduction}

Village development is the concern of the government of the Republic of Indonesia which is used as demand as evidenced by the policies issued by the government through the Ministry of Villages, Development of Disadvantaged Regions, and Transmigration as part of global sustainable development (Sustainable Development Goals/SDGs) where policies are outlined in the Village SDGs book which is a grounding of the Global SDGs through Presidential Regulation Number 59 of 2017 concerning the achievement of sustainable development goals. The concept of global SDGs is further grounded by adding 1 development goal so that it becomes 18 core points in sustainable development. The development process is based on the 18th goal, namely dynamic village institutions and adaptive culture.

The purpose of the existence of dynamic village institutions and adaptive culture is to build villages into developed villages without leaving cultural roots which are done by maintaining the cultural roots of village communities, including in development planning (Permendes PDTT, 2018). Villages are required to introduce themselves by developing available local wisdom because each village has its own characteristics. Village development by raising local wisdom of traditional and cultural institutions, ethnicity, especially the role when adapting villagers to face the challenges of change.

Copyright: (c) 2021 the Author(s). This article is an open access article distributed under the terms and conditions of the Creative Commons Attribution (CC-BY) 4.0 license (https://creativecommons.org/licenses/by/4.0/). Published by Al-Kindi Centre for Research and Development, London, United Kingdom. 
Each village has a different way of responding to dynamic village development goals with an adaptive culture. Therefore, the role of the community is to improvise culture in development where all village components must be involved in the formulation of village development planning.

This study aims to determine the factors that support and hinder the implementation of dynamic village institutional programs and adaptive culture in the Southeast Minahasa Regency.

\section{Literature Review}

\subsection{Sustainable Development Goals}

The Village Sustainable Development Goals (Village SDGs) is a global development program, in which the government of the Republic of Indonesia through the Ministry of Villages PDTT added 1 point, namely the 18th point, namely dynamic village institutions and adaptive culture. Village institutions are a very vital component to encourage the sustainability of point development, therefore, the existence of village institutions must be strengthened so that they can support the achievement of sustainable development goals. SDG's Desa strives to maintain local wisdom, as well as revitalize and mobilize all elements of institutions at the village level because the involvement of all village elements can strengthen and function in village institutions in people's lives and become a supporter of the life of diversity in a dynamic village as well as a driver for achieving success. SDG's Village program. In 2018 the population's participation in social activities in the surrounding environment has reached $85.43 \%$ (BPS, 2018). If categorized by place of residence, more rural residents participate in social activities compared to residents who live in urban areas where $88.56 \%$ compared to $82.94 \%$. The three social bonding activities that were most participated in by the age group 10 years and over showed that togetherness activities at death events showed $63,87 \%$, religious $61.87 \%$, and other social activities at $46.82 \%$. To achieve the SDG's Village 2030 goals, several indicators are used, including the sustainability of mutual assistance or mutual cooperation activities; participation of religious leaders in village development activities; protection of villagers against the weak and orphans; preservation of village culture; and solving citizen problems based on a cultural approach.

\subsection{The Implementation of Policies}

An understanding of implementation can be linked to regulation or policy that is oriented towards the interests of the public or the community. The benefits of a policy will be seen if the implementation of the policy has been carried out. Implementation is an important activity of the entire regulatory or policy planning process. According to Santie (2015), implementation comes from English, namely to implement which means to implement. Implementation is the provision of means to carry out something that has an impact or effect on something. Something that is done to have an impact or result can be in the form of laws, government regulations, judicial decisions, and policies made by government institutions in state life. Implementation according to the theory of Johns (2015) "Those activities directed towards putting a program into effect " which means the process of realizing the program to show the results, while according to Horn and Meter who say "Those actions by public and private individuals or groups that are achievement or objectives set forth in prior policy "which means actions taken by the government. In other words, implementation is an action taken after a policy is established where implementation is a way for a policy to achieve its goals.

According to Ratri (2014), policy implementation is an action taken by individuals or groups of government and private which is directed to achieve the goals that have been set in the policy decisions that have been taken previously. This means that the implementation process will not take place until laws or regulations are enacted and funds are provided to finance the process of implementing the policy. Mulyadi (2015) says that implementation refers to actions to achieve the goals that have been set in a decision, this action point seeks to change these decisions into operational patterns and tries to achieve big or small changes as previously decided. Implementation is essentially an effort to understand what should happen after the program is implemented. In practical terms, implementation is the process of implementing basic decisions. The process consists of several stages, namely: 1) the stage of ratification of laws and regulations, 2) the stage of implementing the decision by the implementing agency, 3) the stage of the target group's willingness to carry out the decision, 4) the real impact of the decision, whether desired or not, 5) the impact of the decision. as expected by the policy implementing agency, 6) and the stages of efforts to improve the policy or legislation. In the implementation preparation process, at least several important things are involved, including the preparation of resources, units, and methods as well as policy translation.

\subsection{Public Policy Implementation Model}

In carrying out the implementation of a policy, it will not necessarily go as planned. The success of a policy is influenced by many factors, where the factors that influence policy implementation aim to simplify understanding. Therefore, a policy implementation model is needed. Several models of policy implementation according to experts consist of a model of policy implementation according to George Edward III which has 4 aspects in carrying out policy implementation consisting of communication, resources, disposition, and bureaucratic structure. The policy implementation model according to Merilee S Grindle, the aspects needed in carrying out the implementation of the policy consist of the content of the policy or the content of the policy and the 
implementation environment or the context of implementation. These two aspects include the extent to which the interests of the target group or target group are contained in the policy vision, the types of benefits received by the target group, as well as the extent to which changes are desired from a policy, as well as the location of a program whether it is appropriate Whether a policy has mentioned its implementor in detail and, whether a program is supported by adequate resources. Furthermore, the policy implementation model according to Mazmanian and Sabatier where there are three aspects that affect policy implementation, namely the characteristics of the problem or trackability of the problems, the characteristics of the policy/law, or the ability of statue to the structure implementation and environmental aspects or nonstatutory variables affecting implementation. And the fourth is the policy model according to Van Meter and Van Horn. Where in the policy implementation model, there are five aspects that affect implementation performance, which consist of policy standards and targets, resources, inter-organizational communication, and strengthening of activities characteristic of implementing agents and socio-economic and political conditions.

Based on 4 models of public policy implementation, in this study the researcher focused on the implementation model according to George Edward III, this was based on the aspects used to determine the implementation of policies implemented about dynamic villages and traditional culture which were deemed more suitable to be applied in this study.

\section{Research Method}

This study uses a qualitative research method with a descriptive approach. The location of the research was carried out in 6 subdistricts and villages in Southeast Minahasa Regency. Research informants as research subjects used a key person consisting of the Head of the Village Community Empowerment Service, the Secretary of Balitbang (Research and Development Agency), the subdistrict head, the head of the village and sub-district, the community amounting to 1 person per village and the sub-district which became the research locus located in Southeast Minahasa Regency. This study uses primary data and secondary data. Data was collected by means of observation, interviews, and documentation. Data analysis according to Miles and Huberman (Sugiyono, 2011), consists of data reduction, data presentation, and conclusion drawing.

The phenomenon in research on the implementation of dynamic village institutional programs and adaptive culture in Southeast Minahasa Regency is based on:

1. Communication includes the process of delivering and consistent information about the implementation of dynamic village institutional programs and adaptive culture in the Southeast Minahasa Regency.

2. Resource: The resources in question are human resources as program implementers consisting of the quality and quantity of officers and facilities that support the implementation of policies.

3. Disposition: Implementing commitment and attitude of implementing dynamic village institutional programs and adaptive culture in Southeast Minahasa Regency.

4. Bureaucratic Structure: Availability of operational standards (SOP) and clarity of SOPs for implementing dynamic village institutional programs and adaptive culture in Southeast Minahasa Regency.

\section{Discussion}

\subsection{Communication}

The communication process is carried out by means of intensive socialization and seminars about the importance of dynamic village programs and adaptive culture, this is because each region has different local wisdom that needs to be highlighted and needs to be introduced more widely to the general public even to the national and international levels. The communication process carried out by the implementers of the implementation apart from socialization and seminars, the Regency Government in collaboration with the sub-district and sub-district and village governments continues to provide information about the importance of the dynamic Village program and adaptive culture to the village level even though it is conveyed by village government leaders. which exists. At the village government level, the village government in addition to socializing about this program, the village government works with the community to support each other in introducing the local wisdom available in their village. At every village level community meeting, information about dynamic village programs and adaptive culture is always combined continuously so that the effect of the information provided raises the desire of the community to develop local wisdom such as at the research location where local wisdom is developed and supported by the sub-district and district governments. namely in the manufacture of handicrafts from coconut shells, the formation of cultural studios, and the mutual cooperation program or better known as "Mapalus".

In addition to delivering through activities attended by community groups, the government also communicates using applications in the form of social media that can be a means to convey information about dynamic Village programs and adaptive culture, for example on Facebook, WhatsApp, and Instagram.

\subsection{Resource}


Resources in the implementation of the dynamic Village institutional program and adaptive culture consist of human resources and financial or budgetary resources. In the implementation of this program, human resources show that there is still a lack of understanding about the dynamic Village institutional program and adaptive culture as a whole. adaptive culture, especially in Southeast Minahasa Regency. This causes not all village communities in Southeast Minahasa Regency to respond to the dynamic Village institutional program and adaptive culture. Because there are only a few regions that are trying to show about the improvement of the program being delivered Where they promote local wisdom that is in their village when requested by the district level for example at the birthdays of Southeast Minahasa Regency and Southeast Minahasa Expo as well as in North Sulawesi Province who is known to frequently run expos to introduce existing local wisdom.

In addition to human resources, financial or budgetary resources are very much needed in the implementation of dynamic Village institutional programs and adaptive culture. Therefore, through the Ministry of Villages, PDTT, he instructs that the implementation of the dynamic Village institutional program and adaptive culture can be carried out using the village fund budget that has been disbursed by the central government to each local government. However, based on the results of research conducted by the budget to execute the dynamic Village institutional program and adaptive culture that should be taken from the village fund budget, not all villages run the program on the grounds that the availability of the budget is more focused on infrastructure development in the village. The use of village funds is regulated in the regulation of the Minister of Village Development of Disadvantaged Regions and Transmigration of the Republic of Indonesia number 13 of 2020 concerning the priority of using village funds in 2021 Article 6 paragraph 2 point D which explains inclusive villages to increase the involvement of village women, peaceful villages with justice and create dynamic service institutions and adaptive culture.

\subsection{Disposition}

The implementors who run the dynamic village institutional program and adaptive culture show that they are open to the responses submitted by the community about the dynamic village program and adaptive culture. The disposition of the implementer affects the performance of the policy because if the implementation of the policy is based on the attitude, commitment, and desire to run the policy well, automatically the implementation of the policy can be successful. The research conducted shows that the attitude of the implementers as policy implementers shows a very good thing, this can be seen from the sincerity and willingness of the implementers in carrying out the dynamic Village program and adaptive culture.

\subsection{Bureaucratic Structure}

The bureaucratic structure referred to in this study includes the dimensions of the distribution of responsibility in a policy to different elements. Therefore, coordination is needed. In this coordination, of course, there must be standard operating procedures that can direct and facilitate and equalize the actions of the implementers of policy implementation in carrying out their respective duties. the creative bureau structure on the dynamic Village program and adaptive culture shows the division of activities or tasks between one group and another which is only displayed on the bureaucratic structure but in proper implementation, there must be standard operating procedures that cannot be shown.

Standard operating procedures should be a reference for the steps that must be taken in the process to run a dynamic Village program and an adaptive culture, but in reality, there is no standard operating procedure standard in program implementation.

\subsection{Supporting and Inhibiting Factors of Dynamic Village Institutional Programs and Adaptive Culture in Southeast Minahasa District}

Based on the results of the research conducted, it is found that the supporting and inhibiting factors in the implementation of the dynamic Village institutional program policy and adaptive culture in Southeast Minahasa Regency. Factors that are considered as supporting factors in the implementation of the dynamic village institutional program and adaptive culture in Southeast Minahasa Regency are communication and the disposition of the implementer. The communication aspect is seen from the process of delivering information about the program to be run starting from the district government, sub-district government, and village government to the community as a target or target for implementing policies where the communication process is delivered repeatedly at the village level on activities carried out in the village. so that the main target of the program, which is about local wisdom, is starting to be highlighted and developed by the government which involves massively by the community. Although not all people in the village run the program delivered, there are several villages that cannot run the program due to the response from the community. which is very lacking even though the information received is very good. The communication process carried out is also supported by the disposition of the executor. Where they convey information well and clearly so that it can be done by the community, of course, it is supported by the Village Government, especially because it is closest to the village community.

While the inhibiting factors for the dynamic Village institutional program and adaptive culture in Southeast Minahasa Regency consist of resources and bureaucratic structure. The resources referred to as inhibiting factors in the implementation of this policy 
are financial resources or budgets. Financial resources in implementing the dynamic Village program implementation and adaptive culture depend on the village fund budget that has been given but unfortunately, the village fund budget received which is required to also help In the implementation of the dynamic Village program and adaptive culture which aims to build and develop local wisdom is only focused on infrastructure development in the village. Another inhibiting factor is the bureaucratic structure where the bureaucratic structure can be seen through the composition of government at the provincial level to the rural level, but in the execution of dynamic village program implementation and adaptive culture, there is no standard operating procedure that becomes a reference for program implementation.

\section{Conclusion}

Based on the results of the research conducted, it was concluded that the factors that support the implementation of dynamic village institutional programs and adaptive culture in Southeast Minahasa Regency are communication, which is related to the process of delivering information which is carried out by holding meetings as a form of coordination, through short messages, chat using applications as well as using social media such as Facebook, WhatsApp, and Instagram so as to make information received clearly which makes information about dynamic village institutional programs and adaptive culture not confusing in the community. Meanwhile, the disposition of the implementer, which relates to the commitment of the dynamic village institutional program and adaptive culture, is carried out seriously so that it can be felt by the community, which is supported by the honesty generated by carrying out supervision starting from planning to implementing the program from the apparatus within the Southeast Minahasa Regency government.

Factors that are considered to be obstacles to the implementation of dynamic village institutional programs and adaptive culture in Southeast Minahasa Regency are resources that include the quality and quantity of program implementers in this case the state civil apparatus and government authority in this case program implementers who cannot force the community to carry out programs that have been determined. The next inhibiting factor is the bureaucratic structure where there is no written standard operating procedure (SOP) to implement dynamic village institutional programs and adaptive culture in Southeast Minahasa Regency.

Based on the discussion and conclusions that have been described the factors supporting and inhibiting the dynamic village institutional program and adaptive culture in Southeast Minahasa Regency, there are several inputs as suggestions consisting of:

1. For policymakers or decision-makers, they must make laws that oblige the government, especially the village government to implement a dynamic village program and an adaptive culture that aims to improve local wisdom in the village where local wisdom can be a place to increase economic growth.

2. For the target group or community, it is hoped that there will be good cooperation with the village government in particular and the district government, in general, to help develop existing local wisdom or create activities that can support the progress of the village they live in.

3. Resources, especially financial resources, should determine the amount that must be channeled through the village fund budget as regulated in regulations so that program implementation can be carried out based on available and appropriate financial resources.

4. Standard operating procedures in implementing the dynamic village program and adaptive culture must be well prepared in order to know the steps or stages taken to carry out the dynamic village program and adaptive culture.

\section{References}

[1] Dwi K. R. (2014). Implementasi Peraturan Walikota Probolinggo nomor 36 tahun 2013 tentang kebijakan kota layak anak. Jurnal program studi ilmu pemerintahan, Universitas Brawijaya 2014.

[2] Mulyadi, D. (2015). Studi Kebijakan Publik Dan Pelayanan Publik, Bandung : Alfabeta

[3] Peraturan P. (2017). Tentang pencapaian tujuan pembangunan berkelanjutan.

[4] Santie, J. K. (2015). Implementasi kebijakan program bantuan beasiswa Mandiri di Politeknik Negeri Manado. Jurnal Manajemen Administrasi Publik. Volume 1 Nomor 2.

[5] Statistics Indonesia. 2018.

[6] Sugiyono (2011). Metode Penelitian Kuantitatif Kualitatif Dan R\&D, Bandung: Alfabet 